\title{
EFEKTIVITAS NILAI KEARIFAN LOKAL PADA KEMAMPUAN MENULIS CERPEN MAHASISWA UNIVERSITAS INDRAPRASTA PGRI
}

\author{
Arinah Fransori \\ Universitas Indraprasta PGRI Jakarta \\ arinah.fransori@unindra.ac.id
}

\begin{abstract}
Abstrak
Perkembangan teknologi saat ini yang semakin maju, menggeser dimensi budaya, adat istiadat, nilai-nilai kearifan lokal dalam masyarakat.Di era milenal perkembangan teknologi dan kebiasaan baru muncul, membentuk dimensi baru kehidupan dan melupakan nilai-nilai kehidupan bermasyarakat dan bersosial yang penting.Dalam hal ini nilai kearifan lokal yang perlu terus digali dan dilestarikan tanpa menolak maupun menikmati kebudayaan yang modern seperti sekarang ini. Jika melupakan nilai kearifan lokal yang ada didaerah sama halnya dengan kita melupakan keberadaan peningalan budaya nenek moyang yang sangat bernilai. Penelitian ini mengangkat tema kearifan lokal untuk dipelajari dan dijadikan pendekatan untuk menulis sebuah cerpen.Tujuan penelitian ini ialah untuk mendeskripsikan efektivitas nilai kearifan lokal pada kemampuan menulis cerpen mahasiswa universitas Indraprasta PGRI. Metode yang dipakai metode eksperimen semu (quasi eksperimen).Didapatkan hasil berupa dua buah buku Antalogi Cerpen karya mahasiswa yang berjudul Quardraginta (Lebih Kecil dari Tiga). Dua buah buku yang terdiri atas 2 bagian, yang masing-masing berisi 20 karya cerpen dan total terdiri atas 40 karya cerpen. Hasil uji-t dapat ditarik kesimpulan bahwa ada perbedaan skor rerata antara kelas yang dikenai perlakuan dan kelas kontrol. Diketahui setelah dikonsultasikan pada $t_{\text {tabel }}$ ternyata perbedaan tersebut signifikan, yaitu $\mathrm{t}_{\text {hitung }}>\mathrm{t}_{\text {tabel }}$ atau 3,223 $>2,004$ dengan $\mathrm{db}=55$ pada tingkat signifikansi $95 \%(\alpha=0,025)$.
\end{abstract}

Kata kunci: efektivitas, nilai kerarifan lokal, menulis cerpen

\section{PENDAHULUAN}

Di era kemajuan teknologi saat ini yang semakin maju, menggeser dimensi budaya, adat istiadat, nilai-nilai kearifan lokal dalam masyarakat.Di era milenal perkembangan teknologi dan kebiasaan baru muncul, membentuk dimensi baru kehidupan dan melupakan nilai-nilai kehidupan bermasyarakat dan bersosial yang
penting.Berbagai perubahan terjadi di berbagai bidang kehidupan, baik dalam kehidupan sosial ekonomi, keagamaan, politik maupun dalam dunia pendidikan.Pergeseran bahasa dan budaya cenderung lebih pesat terjadi di era globalisasi saat ini.Di mana pandangan, tuntunan dan ideologi masyarakat pun berubah, ke arah era modern yang lebih dinamis 
dan efisien melupakaan tatanan tradisi dan kebiasan yang dianggap bertele-tele dan tidak kompetibel.

Dalam hal ini pentingnya bagi kita menyadari dan terus menggali potensi dari dalam diri maupun kehidupan bermasyarakat di sekitar kita.Menggali akar budaya kehidupan masyarakat kita yang luhur dan berbudi pekerti baik.Sama halnya nilai kearifan lokal yang perlu terus digali dan dilestarikan tanpa menolak maupun menikmati kebudayaan yang modern seperti sekarang ini. Jika kita melupakan nilai kearifan lokal sama halnya dengan melupakan eksistensi warisan budaya masa lampau yang sangat berharga. Misalnya budaya daerah, dalam suatu masyarakat mempunyai budaya yang diturunkan terus menerus hingga masih terjadi sampai saat ini.Hal ini penting untuk nantinya agar generasi penerus dapat memahami dan melestarikan budaya yang ada di daerahnya. Seperti juga kearifan lokal yang ada di masyarakat kita, begitu beragam yang sering muncul dan tersirat pada karya sastra. Kearifan lokal daerah yang terus dilestarikan dan dilakukan seiring dengan perkembangan zaman (Sartini, 2009).

Hal yang penting dilakukan adalah mengggali potensi nilai-nilai kearifan lokal pada karya sastra daerah.Kearifan lokal atau local wisdom(H Hermanto Suaib, 2017) merupakan kekayaan lokal suatu daerah yang berhubungan dengan pandangan hidup (way life) atau cara melihat dan bertujuan untuk mengakomodasikan kebijakan melalui tradisi yang ada pada suatu daerah. Oleh sebab itu, dapat disimpulkan kearifan lokal tidak hanya sebuah norma-norma dan nilai-nilai budaya saja, tetapi semua unsur gagasan, pandangan dan yang berimplikasi pada teknologi, pembangunan dan estetika.Kearifan lokal merupakan perwujudan kebudayaan yang terjadi dengan penguatan-penguatan dalam kehidupan. Selain itu, dapat memperlihatkan eksistensi masyarakat dalam bentuk humanisasi manusia yang terwujud pada kebudayaan.

Kebiasaan-kebiasaan yang ada pada masyarakat, yang terproses dalam jangka panjang tercermin 
dalam kearifan lokal, berupa nilainilai arif yang terus berlangsung secara terus-menurus. Proses tersebut tercermin pada nilai-nilai yang berlaku pada anggota maupun kelompok masyarakat tertentu. Nilai tersebut sebagai acuan dan pedoman kelompok tersebut serta menjadi hal yang tidak dapat dipisahkan, serta menjadi bagian penting dalam kelompok masyarakat. Kebiasaankebiasaan berupa nilai bisa diamati melalui sikap dan tingkah laku anggota masyarakat. Dengan demikian, revitalisasi berupa upaya pewarisan kearifan lokal selalu diwarisi antargenerasi. Namun, bisa dijadikan bukti bahwa kearifan lokal tetap diakui keberadaanya dalam menghadapi derasnya arus globalisasi, serta memberikan efektivitas dan kemudahan dalam bersosialisasi, maupun mengikuti arus dengan gaya hidup yang pragmagtis dan konsumtif $(\mathrm{H}$ Hermanto Suaib, 2017).

Berdasarkan uraian tersebut, maka perlunya digali nilai-nilai kearifan lokal daerah yang ada di Indonesia, sebagai bentuk identitas dan warisan budaya terdahulu.
Dalam ranah pendidikan, perlunya untuk dipelajari karena pendidikan yang memiliki peran untuk perkembangan generasi muda yang terdidik, terampil, inovatif, beretika dan berbudaya Indonesia. Oleh sebab itu, dalam penelitian ini pada aspek kemampuan menulis mahasiswa diminta untuk mencari informasi sebanyak-banyaknya tentang kearifan lokal yang mereka pahami dan pelajari lalu dituliskan kembali menjadi tulisan dalam bentuk cerpen yang mencerminkan sikap dan budaya kita yang memiliki banyak aneka kearifan lokal daerah.

Menulis adalah bagian terpenting dalam aspek kemampuan berbahasa, dengan menulis mahasiswa akan melewati fase belajar, mendengarkan, membaca, menggali informasi sebanyak-banyak yang akan dijadikan bahan atau materi penulisan. Untuk itu pentingnya kemampuan menulis bagi mahasiswa untuk belajar, menghasilkan karya dan menciptakan ilmu pengetahuan.Menulis juga sebagai bentuk hiburan dan apresiasi seseorang terhadap perasaan, ide, 
pandangan yang dimiliki dan dituangkan dalam bentuk tulisan. Dalam penelitian ini, aspek yang diukur pada kemampuan menulis adalah menulis sastra, dalam hal ini menulis cerpen. Menulis cerpen tidak hanya menghasilkan sebuah cerita pendek yang ber-plot dan berlatar, tetapi menulis cerpen yang didasari pada pengungkapkan nilai-nilai kearifan lokal daerah pada karya cerpen yang mereka tulis.

Menulis merupakan salah satu proses belajar. Oleh sebab itu mahasiswa yang mengalami kesulitan menulis kemungkinan juga memiliki masalah atau kesulitan dalam belajar.Kesulitan belajar dalam bahasa Inggris learning disability berarti ketakmampuan belajar. Kata disability yang berarti kesulitan belajar memberikan kesan yang optimis bahwa setiap orang masih dapat belajar.Tidak mampu dalam hal ini bisa berarti dapat belajar dengan berbagai hasil baik, maupun kurang baik. Di sisi lain, berbagai hambatan yang dialami mahasiswa dalam proses pembelajaran menjadi tolak ukur mengetahui penyebab kesulitan belajar mahasiswa. Dalam hal ini mencari faktor-faktor kesulitan belajar yang dirasakan(Listiani, 2020)

Dalam perkembangannya menulis umumnya amat sangat menjadi kendala bagi mahasiswa maupun pengajar itu sendiri.Banyak faktor yang menyebabkan kesulitan menulis, khususnya menulis cerpen.Menurut

(Owon, 2017)banyak hal yang dapat terjadi pada saat menulis, kesulitankesulitan itu menjadi kendala dosen pada pembelajaran menulis, apalagi menulis kreatif yang sifatnya lebih bebas. Namun, hal ini dapat terjadi karena dalam prototipe bahan ajar, tidak ada peluang bagi mahasiswa untuk memverifikasi tulisannya. Pada umumnya mahasiswa diminta langsung mengumpulkan tulisan supaya teman/dosen menilainya. Dengan demikian, kesalahan ejaan, tanda baca, dan huruf kapital masih banyak ditemukan dalam tulisan mahasiswa. Faktor-faktor tersebut harus diatasi agar dapat menciptakan karya yang utuh dan menjadi bagian dari sebuah karya sastra yang menulis. 
Karya sastra dengan genre fiksi yang disukai banyak remaja adalah cerpen. Cerpen merupakan karya fiksi yang memiliki gaya bahasa yang mudah dipahami serta sederhana. Oleh sebab itu cerpen dapat mudah dimengerti dan bersifat keseharian seperti kehidupan di dunia nyata. Dalam hal ini saat membaca cerpen pembaca akan sekolah merasa sedang membaca tentang diri kita sendiri dalam cerita cepen tersebut. Cerpen adalah karya sastra yang memiliki karakter yang unik, yaitu dengan gaya penceritaan yang pendek dan sederhana, sehingga cerpen mudah diterima, dapat dengan jelas dan mudah untuk dibaca rmudah dipahami dan dimengerti. Sama seperti karya sastra lain yang memiliki kekhasan karya sastra cerpen memiliki keunikan dalam aspek cerita yang fokus, dan padat (Aeni \& Lestari, 2018).

Terkait menganalisis tentang menulis cerpen, penelitian yang dilakukan oleh (Aeni \& Lestari, 2018) juga mengukur kemampuan menulis cerpen. Penelitian tersebut menerapkan metode "mengikat makna" dengan memperoleh hasil pretest dan posttest yang sesuai. Dari hasil penelitian disimpulkan bahwa penerapan metode tersebut efektif digunakan pada pembelajaran menulis cerpen mahasiswa semester VI. Dapat dilihat hasil tes awal 65,5 sedangkan tes akhir menjadi 76,85 . Berdasarkan hasil tersebut dapat dilihat bahwa adanya peningkatan nilai, dengan demikian dapat disimpulkan bahwa metode yang digunakan efektif pada pembelajaran.

Inti sari dari konsep “mengikat makna"adalah pada saat kita ingin menulis, kita memerlukan membaca.Begitu juga sebaliknya pada saat hendak membaca kita memerlukan menulis. Dengan demikian dapat disimpulkan gerakan literasi yang menjadi dasar pada proses pembelajaran akan berhasil diimplementasikan apabila setiap orang memiliki konsep yang sama bahwa membaca memerlukan menulis, sebaliknya menulis memerlukan membaca. Dengan konsep ini, gerakan literasi yang dicanangkan pemerintah akan berhasil karena masyarakat gemar membaca dan menulis. 
Konsepnya penelitian di atas mengaitkan tentang aspek 4 kemampuan berbahasa. Bagaiman jika seseorang yang banyak membaca dan menyimak akan mampu menulis. Penelitian di atas menunjukkan bahwa dengan rajin membaca dan menyimak, maka akan "mengikat makna" atau dalam arti lain memperoleh informasi untuk menulis cerpen. Secara logika, kita dapat menyimpulkan dugaan atau hipotesis dan melakukan pengukuran sebagai bentuk pembuktiannya. Hampir sama dengan penelitian ini, bahwa objek yang jadi sumber rujukan menulis atau informasi/ide menulis adalah dengan menggali potensi kearifan lokal yang ada di daerah. Dengan demikian, penelitian ini juga memberikan masukan dan ide kepada penulis untuk menghasilkan sebuah karya sastra berupa cerpen.

Menulis cerpen bukan hal yang mudah, tetapi tidak dikategorikan sulit juga. Konteksnya seseorang yang kreatif memadupadankan informasi/ide yang diperolehnya dan menuangkannya dalam bentuk tulisan berupa kisah dalam cerpen.Tak harus kisah yang sastra atau menggugah, hal utama adalah mampu menulis cerpen dengan ide dan gagasan mahasiswa masing-masing yang bersumber pada nilai kearifan lokal yang mereka pelajari.

Setelah dilakukan beberapa kali pengamatan, dengan pemberian tugas kepada mahasiswa, mahasiswa cenderung mengalami kesulitan dalam menulis cerpen.Kemampuan menulis mahasiswa masih kurang baik, khususnya dalam menuliscerpen.Berdasarkan pengamatan ditemukan, mahasiswa yang masih tidak tahu penggunaan huruf dan tanda baca. Penggunaan huruf kapital, menulis ejaan, menarasikan kalimat mereka dalam bentuk paragraf dan yang paling mendasar kesulitan menentukan tema apa yang mau mahasiswa tulis. Oleh sebab itu, dalam penelitian ini mahasiswa diminta untuk belajar dan menggali potensi nilai-nilai kearifan lokal yang ada pada kisah karya sastra, khususnya karya prosa (cerpen, novel, cerita rakyat, hikayat, legenda, dongeng dan lain sebagainya). 
Penelitian lain, terkait menggali kearifan lokal juga pernah dilakukan oleh(Himang, Mulawarman, \& Ilyas, 2019). Penelitian ini menggali kearifan lokal untuk menggembangkan bahan ajar dalam menulis cerpen dengan berbasis pengalaman siswa kelas XI SMK.Hasil penelitian menunjukkan uji kepraktisan yang dilihat dari kegiatan pembelajaran (RPP) sebanyak 92\%. Selanjutnya hasil nilai respon guru sebanyak $89 \%$, nilai respons siswa dengan hasil $87 \%$ dengan hasil yang diperoleh rata-rata sebanyak $89 \%$ dengan kriteria hasil sangat praktis. Selain itu, hasil uji keefektifan dapat dilihat dari nilai aktivitas guru yaitu sebanyak 93\%, nilai aktivitas siswa sebanyak 92\% dan hasil dari siswa menulis cerpen yaitu $81 \%$ dengan hasil nilai rata-rata sebanyak $89 \%$ dengan kriteria sangat efektif. Berdasarkan hasil tersebut, disimpulkan bahwa hasil penelitian pengembangan bahan ajar menulis cerpen berbasis pengalaman siswa Kelas XI SMK ini dinyatakan sangat valid, sangat praktis, dan sangat efektif digunakan sebagai bahan ajar menulis cerpen siswa kelas XI SMK.
Penelitian di atas lebih kompleks dan lengkap, dengan mengembangkan terlebih dahulu bahan ajar, juga berupa prototipe yang di uji cobakan untuk beberapa kali.Berdasarkan hasil penelitiannya, bahan ajar yang dikembangkan tersebut dapat membantu siswa menulis.Bahan ajarnya sangat valid, praktis dan efektif digunakan oleh siswa.Mengutip dari penelitian ini juga, peneliti menggali potensi nilai kearifan lokal daerah sebagai bahan dan materi di dalam bahan ajar yang peneliti kembangkan.Dengan demikian, dapat di asumsikan bahwa, memang nilai kearifan lokal dapat membantu mahasiswa untuk menulis.

Berdasarkan uraian di atas, dilakukanlah penelitian ini. Tujuan dalam penelitian ini untuk mendeskripsikan efektivitas nilai kearifan lokal guna meningkatkan kemampuan menulis cerpen mahasiswa universitas Indraprasta PGRI. Dengan kata lain, fokus utama penelitian ini adalah untuk menjawab bagaimanakah keefektifan nilai kearifan lokal dapat meningkatkan kemampuan menulis cerpen 
mahasiswa Universitas Indraprasta PGRI. Dengan demikian, penelitian iniakan bermanfaat baik secara teoritis maupun praktis. Secara langsung akan memperkaya khasanah sastra daerah sebagai wujud kesusastraan Indonesia. Menambah kajian teoritik tentang karya sastra (cerpen) dan strategi

\section{METODE PENELITIAN}

Metode yang digunakan ialah metode penelitian eksperimen Between Group Design (Desain Antar Kelompok). Penelitian ini berjenis penelitian quasiexperimens/quasi eksperimen yang termasuk dalam (pretest-posttest, posttest only).Penelitian eksperimen dalam dunia pendidikan bertujuan untuk menilai suatu tindakan/perlakuan/treatment terhadap tingkah laku mahasiswa atau tentang menguji hipotesis tentang ada atau tidaknya pengaruh tindakan itu bila dibandingkan dnegan tindakan lain (Jaedun, 2011). Eksperimen dapat menunjuk ke beberapa pengertian misalnya sebuah tes atau pengujian.Tes itu biasanya dinyatakan dalam pernyataan kausal. pembelajaran sastra di universitas.Selain itu, juga untuk menambahkan pengetahuan dan semangat melestarikan budaya dan nilai kearifan lokaldikalangan pemuda.Kegiatan ini juga bermanfaat untuk meningkatkan kemampuan menulis mahasiswa khususnya menulis cerpen.

Eksperimen dapat berupa tindakan percobaan atau manipulasi dengan sengaja (Cook, Campbell, \& Day, 1979). Dalam penelitian ini berarti kedua kelompok yang dijadikan sampel akan diberikan tindakan atau perlakuan dengan tata cara tertentu. Dilakukan percobaan secara manipulasi dengan sengaja dan dengan memperhatikan faktor dan kondisi yang ada.

Populasi dalam penelitian ini ialah keseluruhan mahasiswa semester 4 Universitas Indraprasta PGRI Jakarta. Pembelajaran dilakukan di Menulis Kreatif. Jumlah kelas adalah sebelas kelas yang masing-masing terdiri dari kurang lebih 35-40orang. Sampel diambil secara acak, serta bersifat homogen, 
yaitu mengambil secara acak 2 kelas dari sebelas kelas yang ada dengan mengadakan undian. Memilih secara acak, dua kelas dari sebelas dengan cara diundi sehingga didapat Reguler 4 A dan Reguler 4 B. Jumlah sampel seluruhnya adalah 79orang mahasiswa.

Prosedur dalam penarikan sampel sebagai berikut.

1. Mendata semua mahasiswa semester 4 yang mengambil mata kuliah Menulis Kreatif, kemudian dijadikan sampel.
2. Memilih secara acakdua kelas dari seluruh kelas dengan cara diundi sehingga didapat kelas Reguler 4A dan Reguler 4B.

3. Jumlah sampel seluruhnya adalah 79 orang mahasiswa. Dengan perinciaan kelas Reguler 4A menjadi kelompok eksperimen dan Reguler 4B menjadi kelompok kontrol. Berikut ini adalah uraian sampel berdasarkan tabel.

Tabel 1. Sampel Penelitian

\begin{tabular}{|l|c|c|}
\hline No. & Kelas & Jumlah \\
\hline 1 & Reguler 4 A & 40 \\
\hline 2 & Reguler 4 B & 39 \\
\hline & Jumlah & 79 \\
\hline
\end{tabular}

Teknik pengumpulan data yang dilakukan yakni berupa tes. Tes yang digunakan adalah tes kemampuan menulis cerpen. Mahasiswa di kelas eksperimen disuruh mencari karya-karya sastra daerah.Misalnya.cerita rakyat, dongeng, legenda, lagu daerah, atau kisah-kisah terkemuka dari daerah di
Indonesia.Kemudian mahasiswa memilih salah satu karya sastra, misalnya sebuah legenda.legenda tersebut dibaca, dipahami dan digali unsur nilai kearifan lokalnya. Selanjutnya, mahasiswa akan menulis kembali karya sastra tersebut dalam bentuk karya sastra (cerpen) dengan versi yang berbeda. 
Dengan ide cerita yang didasarkan pada nilai kearifan lokal sebuah daerah. Cerpen juga ditulis dengan bebas, sekreatif mungkin atau dengan gaya bahasa yang menggugah. Hasil karya mahasiswa dikumpul dan dinilai sebagai hasil tes kemampuan menulis cerpen.Tes ini bertujuan untuk mengukur kemampuan menulis mahasiswa. Teknik ini, bertujuan untuk membandingkan hasil di kelas eksperimen dan kelas kontrol. Dengan tes ini dapat diketahui efektivitas nilai kearifan lokal pada kemampuan menulis cerpen mahasiswa.

Tes dilakukan dua kali, yaitu di permulaan dan di akhir pada kedua kelas. Tes awal dilakukan pra pembelajaran di kelas eksperimen dan kelas kontrol berlangsung. Tes awal bertujuan untuk mengetahui kemampuan menulis mahasiswa di kedua kelas tersebut. Tes akhir dilakukan pasca kelas eksperimen mendapat perlakuan dan kelas kontrol dengan metode konvensional. Tes akhir bertujuan untuk mengetahui perbandingan mahasiswa kedua kelas
tersebut.Maksudnya, sebelum dilaksanakan tes akhir, dilakukan pengajaran mengenai nilai kearifan lokal pada kelas eksperimen. Selanjutnya, kegiatan pengajaran menulis dengan metode pengajaran konvensional pada kelas kontrol.Teknik konvensional merupakan teknik yang biasa digunakan oleh dosen dalam menulis sastra.Teknik ini diterapkan pada mahasiswa kelompok kontrol, dengan dosen yang mengajarkannya.Langkah-langkah pengajaran menulis cerpen pada kelas kontrol dengan metode konvensional diuraikan berikut ini.

1. Dosen menjelaskan materi mengenai nilai kearifan lokal

2. Mahasiswa diminta dosen untuk mencari ide atau tema menulis.

3. Mahasiswa menentukan temaapa yang akan mereka tulis.

4. Mahasiswa menulis sebuah cerpen secara mandiri

5. Mahasiswa dan dosen bersama-sama menilai 
karya cerpenyang mereka buat.

Dalam setiap penelitian, instrumen yang digunakan untuk mendapatkan data tersebut harus memenuhi syarat sebagai alat yang sesuai atau (valid).Instrumen yang dapat mengukur atau mempunyai reabilitas (konsistensi/keajegan) yang handal. Bila instrumen tidak dapat memenuhi hal tersebut, maka data yang diperoleh dapat diragykan hasilnya (Khumaedi, 2012). Oleh sebab itu, untuk mengolah data sebagai tolok ukur penelitian merupakan aspek yang utama.Instrumen disusun berdasarkan komponen yang sesuai dalam aspek menulis cerpen.

\section{Teknik Analisis Data}

Analisis data adalah
pengolahan data secara
statistik.Setelah memperoleh
data, kemudian diolah dan
dianalisis. Analisis data pada
penelitian kuantitatif menurut
(Neolaka, 2014)adalah sebagai
berikut.

a) Paparan data kuantitatif sesuai masing-masing variabel penelitian dalam bentuk tabel atau tabulasi data.

b) Pengujian prasyarat data sebelum dilakukan tahapan selanjutnya

c) Membuat sebaran data atau tabel distribusi frekuensi dari masing-masing variabel penelitian

d) Sebelum melaksanakan pengujian hipotesis dilakukan terlebih dahulu uji prasyarat analisis yaitu uji normalitas dan uji homogenitas data.

e) Melaksanakan pengujian hipotesis sesuai masingmasing potesis sesuai masing-masing hipotesis yang mengacu pada hipotesis statistik.

f) Kemudian diakhiri dengan merumuskan kesimpulan, implikasi dan saran.

Berdasarkan langkah tersebut, untuk melakukan analisis data digunakan program komputer SPSS 17 dengan langkah berikut ini. 
1) Menghitung nilai rata-rata tes kelas eksperimendan kelas kontrol yang diperoleh dari tes awal dan tes akhir.

2) Menghitung perbandingan perbedaan antara nilai tes awal dan nilai tes akhir mahasiswa kelompok eksperimen dan kelompok kontrol dengan rumus uji t.

3) Menentukan signifikansi hasil tes awal dan tes akhir pada kelompok eksperimen dan kelompok kontrol.

4) Mencocokkan hasil perhitungan dengan tabel nilai titik t.

5) Menginterpretasikan data.

6) Menyimpulkan data

\section{HASIL DAN PEMBAHASAN}

\section{Hasil Penelitian}

Dapat diketahui bahwa pembelajaran dengan pendekatan nilai kearifan lokal dapat meningkatkan kemampuan menulis cerpen mahasiswa Universitas Indraprasta PGRI Jakarta. Hasil penelitian menunjukkan bahwa ada perbedaan kemampuan menulis cerpen antara mahasiswa dengan pendekatan nilai kearifan lokal dan mahasiswa yang diajar dengan metode konvensional. Diketahui bahwa pendekatan nilai kearifan lokal lebih efektif digunakan dalam pembelajaran menulis cerpen. Hal tersebut diperoleh berdasarkan data siswa kelompok kontrol saat tes awal nilai terendah 43,00 dan nilai tertinggi 68,00. Kemudian pada tes akhir nilai terendah 49,00 dan nilai tertinggi 81,00. Sementara itu, siswa kelompok eksperimen pada tes awal nilai terendah 51,00 dan nilai tertinggi 70,00 dan diketahui pada tes akhir nilai terendah 58,00 dan nilai tertinggi 84,00.

Dilihat dari skor tes yang telah diperoleh mahasiswa, penelitian ini tergolong penelitian yang berhasil. Dapat diketahui dari skor tes yang dicapai sebesar 23, 03 poin, dengan rata-rata 78,93.

Dengan adanya perbedaan kemampuan menulis cerpen antara mahasiswa yang diajar dengan pendekatan nilai kearifan lokal dan dengan metode konvensional, maka dapat dinyatakan bahwa penerapan pendekatan nilai kearifan lokal lebih efektif dan memiliki pengaruh 
dibandingkan dengan model konvensional pada mahasiswa Universitas Indraprasta PGRI.

Dari hasil uji-t kedua kelompok disimpulkan bahwa ada perbedaan skor rata-rata antara kelompok eksperimen dan kelompok kontrol. Diketahui setelah dikonsultasikan pada $t_{\text {tabel }}$ ternyata perbedaan tersebut signifikan. Hal itu dapat diketahui dari pengujian uji-t yang menunjukkan bahwa $t_{\text {hitung }}>t$ tabel atau 3,223 $>2,004$ dengan $\mathrm{db}=$ 55 pada tingkat signifikansi $95 \%(\alpha$ $=0,025)$.

Setelah melakukan penelitian dengan strategi tersebut, terdapat 40 karya cerpen mahasiswa yang terdiri atas 2 buku kumpulan Antologi Cerpen karya mahasiswa. Karya tersebut kemudian dikumpulkan dalam dua buku Antalogi yang berjudulQuardraginta (Lebih Kecil dari Tiga) Bagian 1 dan Bagian 2 karya mahasiswa R4A.Berikut ini cover Buku Antalogi Cerpen karya mahasiswa dari kelas eksperimen.

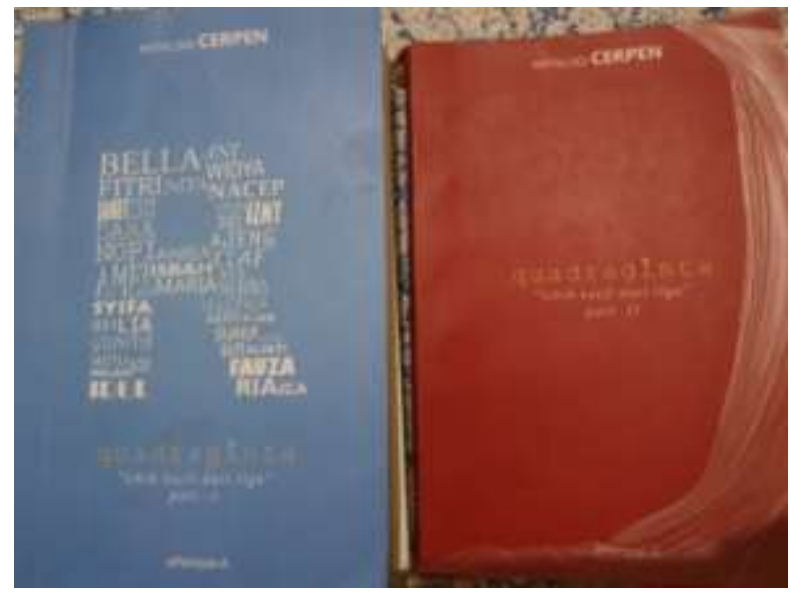

Gambar. 1 Desain Sampul dan

\section{Daftar Isi Buku Antologi Sastra} Karya Mahasiswa

\section{Pembahasan}

Berdasarkan hasil tes awal pada kelompok eksperimen, diketahui skor kelompok eksperimen terendah ialah 56,9611 dan tertinggi 61,1169 dengan skor rata-rata 59,0690. Pada sisi lain nilai tes awal kelompok kontrol terendah 51,2194 adalah dan tertinggi 52,209 dengan skor rata-rata 53,714.

Nilai mahasiswa pada kelompok eksperimen dan kelas kontrol pada saat tes awal belum mendapatkan nilai maksimal merupakan satu hal yang wajar, mengingat mahasiswa belum mengetahui bagaimana menulis cerpen.Supaya mendapatkan hasil penelitian yang valid, maka skor 
nilai tes awal dan tes akhir pada kelompok kontrol juga diuji secara normalitas dan homogenitas.Setelah diuji normalitas dengan menggunakan program komputer SPSS 17, dengan teknik Distribusi Chi Kuadrat maka Ho diterima sehingga menunjukkan data homogen. Kemudian data dari uji grafik P-P Plot yang dilakukan data berdistribusi normal. Hal ini menunjukkan apa yang dikatakan sebelumnya bahwa kemampuan menulis mahasiswa Universitas Indraprasta PGRI itu tidak jauh berbeda atau homogen.

Dari hasil tes akhir kelas eksperimen setelah diberikan $3 \mathrm{x}$ perlakuan pendekatan nilai kearifan lokal untuk menulis cerpen hasil tes akhir diketahui skor tes akhir mahasiswa terendah 58,00 dan tertinggi 84,00 dengan rata-rata skor 69,10. Di sisi lain hasil tes akhir kelompok kontrol diketahui skor tes akhir mahasiswa terendah 49,00 dan tertinggi 81,00 dengan rata-rata skor 63,10 .

Penjelasan di atas dapat diartikan bahwa kemampuan menulis cerpen pasca perlakuan mengalami peningkatan. Berdasarkan hasil perhitungan nilai kelompok eksperimen rata-rata skor tes awal 58,5517 dan rata-rata tes akhir 70,9310, terdapat peningkatan skoryang sebesar 12,37931, sedangkan hasil belajar kelompok kontrol dengan rata-rata skor tes awal 53,7143 dan tes akhir 62,9643 terdapat peningkatan skor sebesar 9,25000.

Dari hasil pengujian uji-t kedua kelompok penelitian, disimpulkan bahwa terdapat perbedaan skor rata-rata kelompok eksperimen dan kelompok kontrol. Diketahui setelah dikonsultasikan pada $t_{\text {tabel }}$ ternyata perbedaan tersebut signifikan. Hal itu dapat diketahui dari pengujian uji-t yang menunjukkan bahwa $\mathrm{t}_{\text {hitung }}>\mathrm{t}$ tabel atau 3,223>2,004 dengan $\mathrm{db}=55$ pada tingkat signifikansi $95 \%(\alpha=$ 0,025).

Keberhasilan dalam peningkatan menulis cerpen pada kelas eksperimen dipengaruhi oleh pendekatan yang digunakan. Proses menulis mahasiswa akan mampu dikembangkan dengan pendekatan tertentu. Proses menulis yang 
dilakukan dengan tahapan-tahapan yang membantu mahasiswa untuk mengembangkan ide, gagasan maupun pemikiran dalam menulis. Pengaruh pendekatan nilai kearifan lokal dalam menulis dengan petunjuk dan langkah-langkah dalam menulis tersebut.

Untuk memperoleh hasil belajar lebih baik tentu memerlukan model pembelajaran lain, strategi atau teknik yang lebih efektif. Pembelajaran dengan pendekatan nilai kearifan lokal juga selain memiliki kelebihan terdapat pula kelemahan. Pada umumnya diketahui, bahwa tidak ada model/pendekatan pembelajaran yang sempurna, setiap model atau pendekatan dalam pembelajaran mempunyai keunggulan dan kekurangan, serta saling melengkapi.

Umumnya mahasiswa merasa kurang tertarik dengan pembelajaran menulis. Kesulitan mahasiswa untuk menuangkan ide ke dalam sebuah kalimat menjadi kendala. Oleh sebab itu, dengan menggali cerita dari kisah-kisah narasi dan nilai-nilai kearifan lokal lebih memberi inspirasi. Kelemahan pada penelitian iniyaitu pada alokasi waktu, dalam 1x pertemuan kadang sulit untuk melakukan proses sampai selesai. Mahasiswa pada prosesnya menceritakan kembali isi tulisan yang mereka baca dan menulis kembali karangan dengan kalimat mereka sendiri.Walau ini membantu, tapi khawatirnya hal ini akan menghalangi mahasiswa untuk menulis secara kreatif melalui ide mereka sendiri, sehingga tidak terlihat kemampuan berbahasa mahasiswa. Pada proses menulis mahasiswa dituntut dalam banyak hal, misalnya kepandaian pemilihan diksi, kosakata maupun organisasi kalimat. Dengan demikian, pada akhir bahasan ini peneliti menyimpulkan bahwa penelitian ini telah berhasil dalam meningkatkan kemampuan menulis mahasiswa. Berdasarkan hasil yang diperoleh berbeda antara kelompok eksperimen yang menerima perlakuan dengan pendekatan nilai kearifan lokal dan kelompok kontrol dengan metode konvensional. Adanya perbedaan kemampuan kedua kelas tersebut, dapat dikatakan bahwa pendekatan nilai kearifan lokal lebih efektif 
digunakan untuk meningkatkan kemampuan menulis mahasiswa, dibuktikan dengan adanya perbedaan hasil pembelajaran dengan metode konvensional.

\section{SIMPULAN}

Dapat disimpulkan bahwa nilai kearifan lokal yang dilakukan dalam strategi pembelajaran memberikan pengaruh terhadap kemampuan menulis cerpen mahasiswa. Hasil menunjukkan bahwa adanya perbedaan hasil dengan perlakuan/tindakan dibandingkan dengan yang diajar dengan metode konvensional. Diketahui adanya unsur efektivitas nilai kearifan lokal pada kemampuan menulis cerpen mahasiswa. Hal ini ditunjukan dengan hasil buku kumpulan antalogi cerpen karya mahasiswa.

\section{DAFTAR PUSTAKA}

Aeni, E. S., \& Lestari, R. D. (2018). Penerapan metode mengikat makna dalam pembelajaran menulis cerpen pada mahasiswa IKIP Siliwangi bandung. Semantik, 7(1).

Cook, T. D., Campbell, D. T., \&
Day, A. (1979). Quasiexperimentation: Design \& analysis issues for field settings (Vol. 351). Houghton Mifflin Boston.

H Hermanto Suaib, M. M. (2017). Suku Moi: nilai-nilai kearifan lokal dan modal sosial dalam pemberdayaan masyarakat. An1mage.

Himang, V. H., Mulawarman, W. G., \& Ilyas, M. (2019). Pengembangan Bahan Ajar Menulis Cerpen Berbasis Pengalaman Siswa Kelas XI SMK. Diglosia, 2(2), 93-102.

Jaedun, A. (2011). Metodologi penelitian eksperimen. Fakultas Teknik UNY, 12.

Khumaedi, M. (2012). Reliabilitas Instrumen Penelitian Pendidikan. Jurnal Pendidikan Teknik Mesin, 12(1).

Listiani, F. D. (2020). FAKTOR PENYEBAB KESULITAN MENULIS FABEL DAN MODEL PEMBELAJARAN YANG DIHARAPKAN MAHASISWA PENDIDIKAN BAHASA DAN SASTRA INDONESIA UNIVERSITAS SANATA DHARMA. KREDO: Jurnal Ilmiah Bahasa Dan Sastra, 4(1), 112-128.

Neolaka, A. (2014). Metode Penelitian dan Statistik, Bandung: PT. Remaja Rosdakarya.

Owon, R. A. S. (2017). 
Efektivitas Nilai Kearifan Lokal Pada Kemampuan Menulis Cerpen Mahasiswa Universitas Indraprasta PGRI

Pengembangan bahan ajar menulis berbagai jenis teks bertema kearifan lokal Sikka bagi siswa SMP. JINOP (Jurnal Inovasi Pembelajaran), 3(1), 528-541.
Sartini, N. W. (2009). Menggali nilai kearifan lokal budaya Jawa lewat ungkapan (Bebasan, saloka, dan paribasa). Jurnal Ilmiah Bahasa Dan Sastra, 1, 28-37. 